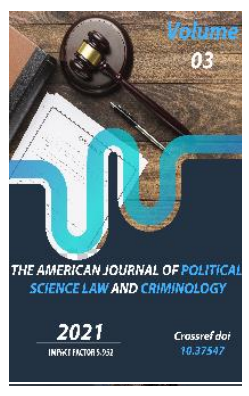

\title{
Legal Analysis Of Crimes Committed In The Field Of Economics
}

\author{
Allanov Said Akbarxon \\ Tashkent State University Of Law, Theory And Practice of The Application Of Criminal Law \\ Specialty Student, Uzbekistan
}

Journal Website: http://usajournalshub.c om/index,php/tajpslc

Copyright: Original content from this work may be used under the terms of the creative commons attributes 4.0 licence.

\section{ABSTRACT}

This article examines the fact that in a modern market economy, in which entrepreneurial activity is widely developed, the introduction of penalties, and not the use of incentive norms in the commission of criminal acts related to economic activity. Our current criminal legislation provides for more exemption from punishment in incentive norms, therefore today in the criminal legislation there are proposals for improving incentive norms aimed at exemption from liability.

\section{KEYWORDS}

Incentive norm, harm caused, crime, criminal liability, release from criminal liability, release from criminal punishment.

\section{INTRODUCTION}

Economic crime is a complex set of several dozen criminal offenses provided for in criminal law. Some researchers include economic crimes as greedy official crimes, especially bribery. Thus, the high level of social risk of economic crime is reflected in the fact that it has a negative impact on the institutions of society, the material basis of the state - a 
violation of the established order of economic activity. It is characterized by some peculiarities:

\section{THE MAIN RESULTS AND FINDINGS}

1. The level of latency of crimes in the field of economics is much higher. Most of them are not identified based on applications from citizens and officials. They are carried out by persons authorized to manage the property and ensure their integrity. The mortality rate of some new types of economic crimes is relatively low (e.g., fraud in obtaining bank loans). The same can be said about the level of latency of a dangerous crime such as counterfeiting.

2. Crimes against the fundamentals of the economy cause great harm to society.

3. Crime in the economic sphere can become a way of life for the majority of the population, forming a semi-criminal mentality.

4. Crime in the field of economics is by its nature almost completely organized. In most foreign countries, organized crime mainly controls the sources of criminal income - casinos, drug trafficking, racketeering, arms sales, while in some countries it controls the entire economy.

The concept of economic crimes is defined in the Criminal Code of the Republic of Uzbekistan as socially dangerous acts that harm the national economy, its industries or sectors or pose a real risk of such damage. The commission of such crimes causes material damage to individuals, public associations or the state. In this context, it can be said that economic crimes are considered as the basis of social relations and the basic system in which the protection of economic interests from criminal encroachment is the object of this type of crime. The interests of the economy are expressed in the relations related to the distribution of material goods, their production and use, as well as in the distribution of the products of labor.

By crimes in the economic sphere, we mean socially dangerous acts defined in the Criminal Code of the Republic of Uzbekistan, which harm the national economy, its branches or branches or pose a real risk of such harm. In the third section of the Criminal Code of the Republic of Uzbekistan, the crimes in the economic sphere were discussed.

Crimes related to sabotage of business activities, unlawful interference, and other crimes that infringe on the rights and legitimate interests of business entities.

In all of these crimes in the economic sphere, the related object is the social relations that provide important interests in the economic sphere [1]. The interests of the economy are expressed in the relations related to the distribution of material goods, their production and use, as well as in the distribution of the products of labor.

Objectively, crimes related to economic cohaci are coded in action or inaction. Crimes in the field of economics can also be divided into the types of crimes (formal) that determine the condition of causing certain consequences (material content) or do not provide for the occurrence of such consequences as necessary features. In order to assess the completion of a crime in a crime in a material economy, it is necessary to have a certain consequence provided by law. In the formal compositional types of crimes in the economic sphere, the fact that an act representing the objective aspect of the crime provided for in the norm of 
the law means that the crime has been completed. In crimes in the economic sphere, the acociy narca is the identification of the causal link between this act and the resulting criminal consequence. This is because a causal link means that any circumstance that has not been identified will not produce the content of the offense under analysis.

Regarding the issue of liability and impunity for non-economic crimes, the Criminal Code of the Republic of Uzbekistan, in addition to crimes in the economic sphere, includes crimes against the person, crimes against peace and security, crimes against the public, environmental authorities, environmental authorities, environmental authorities. liability for crimes against the order of activity, crimes against public safety and public order, and crimes against the order of military service. There is a norm that punishment in the form of restriction of liberty and imprisonment shall not be applied if the material damage inflicted in the following crimes not related to economic cohaci is compensated in the amount of three times.

Article 132 of the Criminal Code establishes criminal liability for the deliberate destruction, destruction or damage to historical or cultural monuments taken under state protection.

If a person has previously been subjected to an administrative penalty under Article 64 of the Code of Administrative Offenses for the same act, the Criminal Code provides for criminal liability under Article 132, Part 1.

The object of the crime is the protection of interests such as the protection of social morals, historical monuments and cultural values.
The crime of hijab has been completed from the moment of destruction, or damage, or damage to historical or cultural monuments protected by the state. At what point the shikact is delivered does not affect the qualification [2].

A person who commits this socially dangerous act shall be compensated three times the material damage, and shall not be subject to punishment in the form of restriction of liberty or deprivation of liberty. As a result of this act, the state suffers material damage, and therefore, if the legislature compensates for the material damage in the amount of three times, the penalty of restriction of liberty and imprisonment is not applied. In our opinion, given the material damage caused by this act, it would be expedient to add to Article 132 of the Criminal Code the provision that if the offender commits the crime for the first time, the offender will be released from punishment if he sincerely regrets his guilt.

Illegal misappropriation of confiscated property, that is, appropriation, racketeering, concealment, destruction or damage of occupied or mortgaged property by a person to whom it is entrusted, can lead to significant damage, as well as to bank or other lending. Article 233 of the Criminal Code provides for liability for banking operations with funds (deposits) occupied by an employee of the organization.

The object of the crime of misappropriation of occupied property is the normal operation of the judiciary. An additional object of this crime will be the rights of the state (if it is a debt on the conversion of state income or property) or other owners, which can be recovered from the hijab of property confiscated from the offender. The authority of the judiciary and the 
investigating authorities must also be recognized as the object of unlawful misappropriation, embezzlement, concealment, destruction or complaint. Objectively, the crime is expressed in the misappropriation, carf, concealment, destruction or damage to property that is registered or confiscated or the subject of bail [3]. That is, as a result of this act, the acocan will also suffer material damage. Therefore, the legislature has established an incentive norm in Article 233 (2) of the Criminal Code, which prohibits the application of the penalty of imprisonment, with compensation of the material damage caused to the offender in triplicate. In our opinion, Article 233 of the Criminal Code stipulates that a person who has committed a crime for the first time shall be released from liability if he eliminates the consequences of unlawful misappropriation of the seized property within thirty days from the date of the crime and compensates three times the material damage. it would be expedient to enter the band.

Among the signs of the objective side of a particular crime are the essential typical signs of the external side of this type of crime in their generalized expression, distinguished from the countless possible manifestations of the corresponding type of crimes committed in reality [4].

\section{CONCLUSION}

In order to prosecute any person who has committed a socially dangerous act, there must be acocs specified in the law. However, the principle of inevitability of liability provided for in Article 10 of the Criminal Code does not imply that a penalty must be imposed. Hucucan, in the decision of the Plenum of the Supreme Court of the Republic of Uzbekistan
"On the practice of sentencing for crimes committed by judges", it is stated that they should discuss the exemption from liability and punishment in accordance with Articles 65, 66, 70, 71 of the Criminal Code [5]. In our opinion, the following can be included in the list of such crimes.

\section{REFERENCES}

1. Kabulov R., Otajonov AA Crimes in the economic sphere. Study guide. - Tashkent: Academy of the Ministry of Internal Affairs of the Republic of Uzbekistan, 2013. - B. 6.

2. Rustamboev.M.H Comments on the Criminal Code of the Republic of Uzbekistan. Special edition. Tashkent // Adolat // 2016. - P.401.

3. Rustamboev.M.H Comments on the Criminal Code of the Republic of Uzbekistan. Special edition. Tashkent // Adolat // 2016. - P.223.

4. Khudaykulov F. K. Signs Of The Objective Side Of Crime In The Theory Of Criminal Law Belonging To The Romano-Germanic Legal Family: Theoretical And Practical Problems //The American Journal of Political Science Law and Criminology. 2021. - T. 3. - №. 01. - C. 57-62.

5. Resolution of the Plenum of the Supreme Court of the Republic of Uzbekistan dated February 3, 2006 "On the practice of sentencing for crimes by judges". Www.lex.uz.

6. Худайкулов Ф. Х. Қилмишни квалификация қилишда жиноят таркиби зарурий ва факультатив белгиларининг ўрни: тахлил ва таклиф //ЖУРНАЛ ПРАВОВЫХ ИССЛЕДОВАНИЙ. - 2020. - Т. 5. - №. 1. 
Doi: https://doi.org/10.37547/tajpslc/Volume03Issue04-11

7. Khaydarov Shukhratjon Djumayevich // GENERAL DESCRIPTION OF THE CRIME OF HIJACKING A VEHICLE // MODERN SCIENTIFIC CHALLENGES AND TRENDS: a collection scientific works of the International scientific conference (28th February, 2021) - Warsaw: Sp. z o. o. "iScience", 2021. Part 2 - 152 p.

https://sciencecentrum.pl/wpcontent/uploads/2021/03/MODERN_SCIEN TIFIC_CHALLENGES\%2037\%20Part\%202\%20 (web).pdf

8. Allanova A. Leaving and entering illegally the Republic of Uzbekistan (instructions and specific features) //Review of law sciences. - 2018. - T. 2. - №. 2. - C. 29. 